\title{
Simulation of Microbial Processes in Estuarine Sediments using Gel-stabilized Systems
}

\author{
By G. T. MACFARLANE, "† MOYA A. RUSS, S. M. KEITH \\ AND R. A. HERBERT \\ Department of Biological Sciences, The University of Dundee, Dundee DDI 4HN, UK
}

(Received 26 April 1984; revised 29 June 1984)

\begin{abstract}
Gel-stabilized model systems have been developed which simulate the physico-chemical gradients found in estuarine sediments of the River Tay, Scotland. Depth profiles of $E_{\mathrm{h}}$ and $\mathrm{pH}$, and of concentrations of $\mathrm{NH}_{4}^{+}, \mathrm{NO}_{2}^{-}$and $\mathrm{NO}_{3}^{-}$and dissolved $\mathrm{O}_{2}$ which developed within the gels were similar to those measured in situ in the sediments. The spatial distribution of populations of nitrifying, nitrate respiring and sulphate reducing bacteria in mature gels showed a good correlation with those recorded in the surface sediments of Kingoodie Bay in the Tay estuary. These data show that NHt oxidation by autotrophic nitrifying bacteria (Nitrosomonas and Nitrobacter) plays a significant role in the development of $\mathrm{pH}, \mathrm{NH}_{4}^{+}, \mathrm{NO}_{2}^{-}$and $\mathrm{NO}_{3}^{-}$gradients within the gels, indicating that similar processes may also operate in situ in these sediments.
\end{abstract}

\section{INTRODUCTION}

Sediments are heterogeneous environments where rapid changes in physical and chemical gradients develop over extremely short vertical and horizontal distances. As a consequence, anaerobic processes, e.g. sulphate reduction, can occur in ostensibly aerobic regions of sediments (Jergensen, 1977). The development of these micro-niches within sediments exerts a profound effect on the metabolic activities and therefore the mineralization processes which can be performed by the indigenous microflora. Estuarine sediments are areas of intense microbial activity (Wood, 1965; Jorgensen, 1980) and most authorities are of the opinion that surface sediments (0-5 cm depth) are the most microbiologically active (Sørensen, 1978; Billen, 1982; Macfarlane \& Herbert, 1984). The vertical distribution of bacteria within sediments is largely dependent upon the presence or absence of oxygen and, generally, the distribution of the different physiological types exhibits a zonation similar to the chemical gradients which develop (Mechalas, 1974; Billen, 1982). Thus, a region of nitrate reduction immediately underlies the surface aerobic zone and is in turn succeeded by a zone of sulphate reduction, below which is a region of $\mathrm{CO}_{2}$ reduction. The exchange of materials between the reduced and oxidized sediment horizons is facilitated by diffusion, biopertubation and irrigation. Macfarlane \& Herbert (1984) showed that the upper $3 \mathrm{~cm}$ of Tay estuary sediments were oxidized whereas below this depth they became progressively anaerobic and reduced. Autotrophic nitrification was restricted to the upper oxidized region and distinct gradients of $\mathrm{pH}, \mathrm{NH}_{4}^{+}, \mathrm{NO}_{2}^{-}$and $\mathrm{NO}_{3}^{-}$were also recorded in this zone. Maximum rates of nitrate respiration were also found within the $0-3 \mathrm{~cm}$ horizon of the sediments reflecting the availability of $\mathrm{NO}_{3}^{-}$as a terminal electron acceptor, generated, in part, as an end-product of nitrification. During the summer months significant rates of sulphate reduction were also recorded (Keith \& Herbert, 1982).

In order to study the spatial distribution of these physiologically distinct groups of bacteria, we have used the gel-stabilized systems developed by Wimpenny et al. (1981) to model these microbial processes in the laboratory. The objectives of the present study were to use gel-stabilized

† Present address: Dunn Clinical Nutrition Centre, Addenbrookes Hospital, Cambridge, UK. 
systems to generate physico-chemical gradients similar to those recorded in situ in Tay estuary sediments as a consequence of the metabolic activities of nitrifying, nitrate respiring, sulphate reducing and methanogenic bacteria.

\section{METHODS}

Measurement of physico-chemical characteristics of Kingoudie Bay sediments. Measurements of $\mathrm{pH}, E_{\mathrm{h}}$, temperature, dissolved $\mathrm{O}_{2}$ tension, $\mathrm{NO}_{3}^{-}, \mathrm{NO}_{2}^{-}$and $\mathrm{NH}_{4}^{+}$in the sediments were determined at $1 \mathrm{~cm}$ increments from 0 to $5 \mathrm{~cm}$ depth as described by Macfarlane \& Herbert (1984).

Enumeration of populations of nitrifying, nitrate respiring and sulphate reducing bacteria. Depth profiles of cell population densities of autotrophic nitrifying bacteria ( $\mathrm{NH}_{\downarrow}$ and $\mathrm{NO}_{2}^{-}$oxidizers) and nitrate respiring bacteria were determined at $1 \mathrm{~cm}$ increments from 0 to $5 \mathrm{~cm}$ depth as described by Macfarlane \& Herbert (1984). Sulphate reducing bacteria populations were enumerated by the most probable number (MPN) method (Alexander, 1965) using growth medium $E$ of Postgate (1979). The tubes were incubated under a gas atmosphere of $95^{\circ} \%(\mathrm{v} / \mathrm{v})$ $\mathrm{H}_{2} / 15 \%(\mathrm{v} / \mathrm{v}) \mathrm{CO}$ at $25^{\circ} \mathrm{C}$ for $7-10 \mathrm{~d}$. Tubes in which blackening of the culture medium occurred due to the production of FeS were counted as positives and the most probable number of sulphate reducing bacteria was estimated from the statistical tables of Alexander (1965).

Determination of nitrification rates, nitrate respiration rates, sulphate reduction rates and methanogenesis. Nitrification rates in the sediments were determined using the $\left[{ }^{1+} \mathrm{C}\right]$ bicarbonate dark uptake method described by Bilien (1976). Nitrate respiration to gaseous products (denitrification) and to $\mathrm{NH} \ddagger$ were determined using $\mathrm{Na}^{15} \mathrm{NO}_{3}\left(99\right.$ atom\% $\left.{ }^{15} \mathrm{~N}\right)$ as described by Macfarlane \& Herbert (1984). Sulphate reduction rates were determined according to the method described by Senior et al. (1982). Sulphate concentrations in the sediment pore water were determined by a barium sulphate turbidimetric method (American Public Health Association, $1974)$ after precipitation of sulphides by the addition of $1 \%(w / v)$ cadmium acetate. Sulphate reduction rates were calculated by the method of Sorokin (1962).

Methane production in Kingoodie Bay sediments was determined by extruding duplicate $5 \mathrm{~g}$ sub-samples of sediment from each depth horizon into $14 \mathrm{ml}$ sterile serum bottles fitted with Suba-seals and then purging the vessels with oxygen-free nitrogen before incubation at $15^{\circ} \mathrm{C}$. Methane production was followed by removing $100 \mu \mathrm{l}$ headspace gas samples for analysis by gas chromatography with a Gow-Mac model 752 gas chromatograph fitted with a flame ionization detector. The $2 \mathrm{~m}$ stainless steel column ( $2 \mathrm{~mm}$ i.d.) was packed with $80 \cdot 100 \mathrm{mesh}$ Porapak $\mathrm{T}$ and operated isothermally at $100^{\circ} \mathrm{C}$ and with a nitrogen carrier gas flow of $30 \mathrm{ml} \mathrm{min}^{-1}$. Quantitative results were obtained by comparison of peak heights with those obtained by injection of $\mathrm{CH}_{4}$ standards.

Consinucrion of gel model systems. The gel model system described by Wimpenny et al. (1981) was modified and gels were constructed as follows. A basal mineral salts medium of the following composition was used to prepare both the solid and semi-solid agar layers $\left(\mathrm{g} \mathrm{I}^{-1}\right)$ : $\mathrm{MgSO}_{4} .7 \mathrm{H}_{2} \mathrm{O}, 0.15 ; \mathrm{CaCl}_{2} .6 \mathrm{H}_{2} \mathrm{O}, 0.01 ; \mathrm{NaHCO}_{3}, 0.5$ : $\mathrm{FeSO}_{4} .7 \mathrm{H}_{2} \mathrm{O}, 0.014 ; \mathrm{KH}_{2} \mathrm{PO}_{4}, 0.4 ; \mathrm{K}_{2} \mathrm{HPO}_{4}, 4 \cdot 2 ;$ cycloheximide, 0.05 . The $\mathrm{pH}$ of the medium was adjusted to 7.6 before autoclaving at $121^{\circ} \mathrm{C}$ for $15 \mathrm{~min}$. The model system was set up by gelling $100 \mathrm{ml}$ of the basal medium plus $10 \mathrm{~mm}-\left(\mathrm{NH}_{4}\right)_{2} \mathrm{SO}_{4}$ with $1.0 \%(\mathrm{w} / \mathrm{v})$ purified agar (Oxoid). This medium was then aseptically added to a sterile I litre Quickfit reaction vessel and allowed to gel. Approximately $100 \mathrm{ml}$ of a freshly collected, well-mixed sediment sample from Kingoodie Bay (0-5 cm depth) was then evenly layered over the solid gel layer and a semi-solid agar layer $(600 \mathrm{ml})$ containing the basal mineral salis medium plus $0.3 \%(w / v)$ purified agar was then aseptically poured down the side of the vessel to avoid disturbing the sediment layer. The gel model system was then covered with aluminium foil and incubated at $20^{\circ} \mathrm{C}$. The sole source of available carbon in these models was that derived from the sediment layer. In addition to the inoculated gels, controls to which no sediment addition had been made were run as well as gels which contained the nitrification inhibitor $\mathbf{N}$-serve (2-chloro-6-trichloromethyl pyridine) at a concentration of $10 \mathrm{mg} \mathrm{l}^{-1}$.

The semi-solid top layer of each gel system was sampled at $0,4,8,12$ and 13 weeks and the profiles of $\mathrm{pH}, \mathrm{O}_{2}$ tension, $E_{\mathrm{h}}, \mathrm{NO}_{2}^{-}, \mathrm{NO}_{3}^{-}$and $\mathrm{NH}_{4}^{+}$were determined, together with the population densities of nitrifying, nitrate respiring and sulphate reducing bacteria using the methods described earlier. Samples were removed for analysis and cell enumeration using a sterile Pasteur pipette which was attached to a micro-manipulator.

Chemicals. N-serve (2-chloro-6-trichloromethyl pyridine) was a generous gift from the Dow Chemical Co., and $\mathrm{Na}^{15} \mathrm{NO}_{3}\left(99\right.$ atom $\left.\%{ }^{15} \mathrm{~N}\right)$ was obtained from BOC Prochem, London, UK. NaH'+CO, $158 \mathrm{mCi} \mathrm{mmol}^{-1}(2 \cdot 15$ $\left.\left.\mathrm{GBq} \mathrm{mmol}{ }^{-1}\right)\right]$ and $\mathrm{Na}_{2}{ }^{33} \mathrm{SO}_{4}\left[60 \mathrm{mCi} \mathrm{mmol}^{-1}\left(2.2 \mathrm{GBq} \mathrm{mmol}^{-1}\right)\right]$ were obtained from Amersham.

\section{RESULTS}

Microbial processes in Kingoodie Bay sediments

Seasonal rates of nitrification, nitrate respiration, sulphate reduction and methanogenesis have been determined (Keith \& Herbert, 1982; Macfarlane \& Herbert, 1984). Table I 
Table I. Rates of nitrification, denitrification. $\mathrm{NO}_{3}^{-}$dissimilation to $\mathrm{NH}_{4}^{+}$, dissimilatory sulphate reduction and methanogenesis in Kingoodie Bay sediments (June 1982)

$\begin{array}{cccccc}\begin{array}{c}\text { Sediment } \\ \text { depth } \\ \text { (cm) }\end{array} & \begin{array}{c}\text { Results are mean values of three samples: ND. not detected. } \\ \text { Ritrification* }\end{array} & \begin{array}{c}\text { Rate of } \\ \text { denitrification* }\end{array} & \begin{array}{c}\text { Rate of NO- } \\ \text { dissimilation } \\ \text { to } \mathrm{NH}_{4}^{*}\end{array} & \begin{array}{c}\text { Rate of } \\ \text { sulphate } \\ \text { reduction }\end{array} & \text { Methanogenesis } \\ 0-1 & 0.92 & 18.89 & 4.63 & 60.16 & 3.79 \\ 1-2 & \mathbf{0 . 6 7} & 24.44 & 4.72 & 70.14 & 2.80 \\ 2.3 & 0.32 & 11.63 & 3.52 & 76.80 & 14.62 \\ 3-4 & \text { ND } & 4.71 & 2.42 & 58.40 & 16.52 \\ 45 & \text { ND } & 4.43 & 1.69 & 41.75 & 20.44\end{array}$

- $\mu \mathrm{g} N$ (g dry wt sediment) $)^{-1} \mathrm{~d}^{-1}$.

$\uparrow$ nmol $\mathrm{SO}_{3}^{2-}$ reduced $(\mathrm{ml} \text { sediment })^{-1} \mathrm{~d}^{-1}$.

\pm nmol $\mathrm{CH}_{\alpha}$ produced (g dry wt sediment $)^{-1} d^{-1}$.

Table 2. Distribution of nitrifying. $\mathrm{NO}_{3}^{-}$respiring and sulphate reducing bacteria in Kingoodie Bay sediments (June 1982)

\begin{tabular}{|c|c|c|c|c|c|}
\hline \multicolumn{6}{|c|}{ Results are given as cell number ( $\mathrm{g}$ dry wt sediment) $)^{-1}$. } \\
\hline $\begin{array}{l}\text { Sediment } \\
\text { depth } \\
\text { (cm) }\end{array}$ & $\begin{array}{c}\mathrm{NH}_{4}^{+} \\
\text {oxidizing } \\
\text { bacteria }\end{array}$ & $\begin{array}{c}\mathrm{NO}_{2}^{-} \\
\text {oxidizing } \\
\text { bacteria }\end{array}$ & $\begin{array}{c}\text { Denitrifying } \\
\text { bacteria }\end{array}$ & $\begin{array}{c}\text { Bacteria } \\
\text { dissimilating } \\
\mathrm{NO}_{3}^{-} \text {to } \mathrm{NH}_{4}^{+}\end{array}$ & $\begin{array}{l}\text { Sulphate } \\
\text { reducing } \\
\text { bacteria }\end{array}$ \\
\hline $\begin{array}{l}0-1 \\
1-2 \\
2-3 \\
34 \\
4-5\end{array}$ & $\begin{array}{l}7.0 \times 10^{3} \\
\text { No data } \\
6.0 \times 10^{3} \\
\text { No data } \\
3.0 \times 10^{3}\end{array}$ & $\begin{array}{l}1.6 \times 10^{4} \\
\text { No data } \\
7.8 \times 10^{3} \\
\text { No data } \\
3.0 \times 10^{3}\end{array}$ & $\begin{array}{l}1.0 \times 10^{5} \\
1.5 \times 10^{5} \\
8.9 \times 10^{4} \\
9.5 \times 10^{4} \\
4.5 \times 10^{4}\end{array}$ & $\begin{array}{l}5.0 \times 10^{7} \\
6.3 \times 10^{6} \\
1.2 \times 10^{6} \\
8.8 \times 10^{5} \\
2.1 \times 10^{5}\end{array}$ & $\begin{array}{l}3.8 \times 10^{3} \\
4.2 \times 10^{4} \\
6.1 \times 10^{5} \\
4.3 \times 10^{4} \\
3.3 \times 10^{4}\end{array}$ \\
\hline
\end{tabular}

summarizes these rates for the surface sediments of Kingoodie Bay (0-5 cm) in June 1982. Maximum rates of all the processes were recorded in the summer months when the sediment temperatures were highest $\left(19^{\circ} \mathrm{C}\right)$. The data also show that there is a spatial distribution of these processes within the surface sediments. Maximum nitrification rates were recorded in the $0-1 \mathrm{~cm}$ depth horizon of the sediments $\left[0.92 \mu \mathrm{g} \mathrm{N}(\mathrm{g} \text { dry wt sediment })^{-1} \mathrm{~d}^{-1}\right]$ whilst nitrate respiration rates (denitrification and $\mathrm{NO}_{3}^{-}$dissimilation to $\mathrm{NH}_{4}^{+}$) were maximal in the $1-2 \mathrm{~cm}$ horizon. Dissimilatory sulphate reduction occurred over a larger depth profile $(1-3 \mathrm{~cm})$ with maximum rates recorded at a depth of $2-3 \mathrm{~cm}$. Methanogenesis was recorded at all depths but highest rates were recorded at $4-5 \mathrm{~cm}$. Cell population densities of autotrophic nitrifying bacteria, nitrate respiring bacteria (denitrifiers and bacteria dissimilating $\mathrm{NO}_{3}^{-}$to $\mathrm{NH}_{4}^{+}$) and sulphate reducing bacteria followed a similar spatial distribution pattern in the sediments (Table 2) to those recorded for the rates of processes described previously. The progression of different physiological groups from the surface sediment downwards follows the general pattern of aerobes giving way to facultative and then strict anaerobes. Table 1 also shows that sulphate reduction was occurring within the oxic sub-surface sediments in Kingoodie Bay (see Fig. 1). Similar results have been reported by Jergensen (1977) for inshore coastal sediments and have been attributed to the presence of anaerobic, reduced microsites within the predominantly aerobic surface sediments.

\section{Development of physico-chemical gradients in gels}

Comparison of the physico-chemical profiles of Tay estuary sediments (June 1982) with those that developed in the gel model systems after 12 weeks incubation at $20^{\circ} \mathrm{C}$ (Fig. 1) shows that the gradients of $\mathrm{pH}, E_{\mathrm{h}}$ and dissolved $\mathrm{O}_{2}$ tension in both systems were similar. These gradients did not form in uninoculated gels, indicating the role of micro-organisms in these processes. Similarly, a comparison of the profiles of $\mathrm{NH}_{4}^{+}, \mathrm{NO}_{2}^{-}$and $\mathrm{NO}_{3}^{-}$in $\mathrm{Kingoodie}$ Bay sediments and those which developed in the gel system shows comparable gradients (Fig. 2). Concentrations of $\mathrm{NH}_{4}^{+}$increased with depth in both systems whereas the reverse occurred with $\mathrm{NO}_{2}^{-}$and $\mathrm{NO}_{3}^{-}$. 


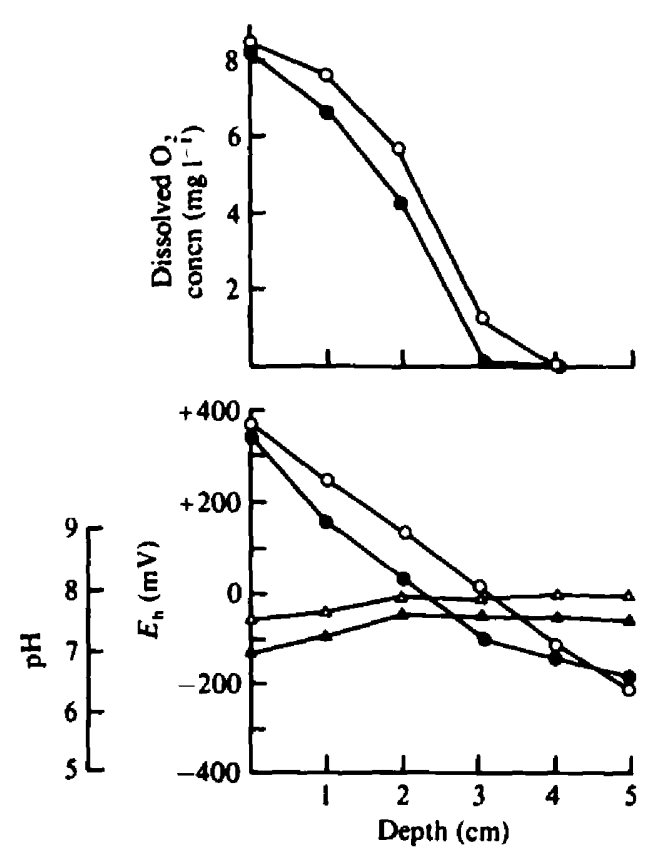

Fig. 1

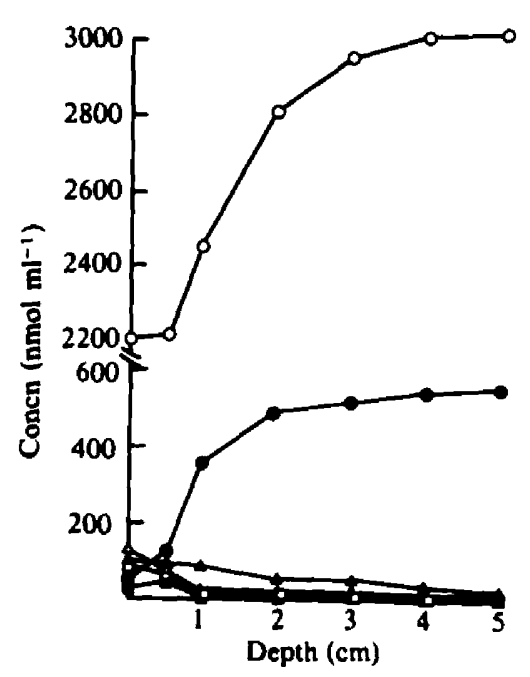

Fig. 2

Fig. 1. Depth distributions of $E_{h}$, dissolved $\mathrm{O}_{2}$ concentration and $\mathrm{pH}$ in $\mathrm{Kingoodie}$ Bay sediments (July 1982 ) and gel sediment systems after 12 weeks incubation at $20^{\circ} \mathrm{C}$. Kingoodie Bay sediments, filled symbols; gel sediments, open symbols; $O, O, E_{\mathrm{h}}$ or $\mathrm{O}_{2}: \Delta, \Delta, \mathrm{pH}$.

Fig. 2. Depth distributions of $\mathrm{NH}_{4}, \mathrm{NO}_{3}^{-}$and $\mathrm{NO}_{\overline{2}}^{-}$in Kingoodie Bay sediments (July 1982) and gel sediment systems after 12 weeks incubation at $20^{\circ} \mathrm{C}$. Kingoodie Bay sediments, filled symbols; gel sediments, open symbols; $\mathrm{O}, \mathrm{O}, \mathrm{NH}_{4} ; \Delta, \triangle, \mathrm{NO}_{\overline{3}}^{-} ; \square, \square, \mathrm{NO}_{\overline{2}}^{-}$.

These chemical gradients failed to develop in control gels which contained no sediment inoculum, providing further evidence for the involvement of micro-organisms in these processes. In the gel model system, $\mathrm{NH}_{4}$ was the sole inorganic nitrogen species present in the medium and so the appearance of $\mathrm{NO}_{2}^{-}$and $\mathrm{NO}_{3}^{-}$in the surface layers of the gel is indicative of nitrification. In mature gels, populations of autotrophic nitrifying bacteria were only detected in the top $1 \mathrm{~cm}$ of the gels (Table 3) and these data correlate well with the observed concentrations of $\mathrm{NO}_{2}^{-}$and $\mathrm{NO}_{3}^{-}$(Fig. 2). To confirm that nitrifying bacteria were essential for the production of $\mathrm{NO}_{2}^{-}$and $\mathrm{NO}_{3}^{-}$from $\mathrm{NH}_{4}^{+}$, inoculated gels were treated with the nitrification inhibitor $\mathrm{N}$-serve $\left(10 \mathrm{mg}^{-1}\right)$ at zero time and examined at periodic intervals for the production of $\mathrm{NO}_{2}^{-}$and $\mathrm{NO}_{3}^{-} \mathrm{NO}_{2}^{-}$and $\mathrm{NO}_{3}^{-}$production could not be detected under these conditions and no nitrifying bacteria could be isolated. The addition of $10 \mathrm{mg} \mathrm{N}$-serve $1^{-1}$ to mature gels resulted in the disappearance of the $\mathrm{NO}_{2}^{-}$and $\mathrm{NO}_{3}^{-}$gradients within $7 \mathrm{~d}$ and the $\mathrm{NH}_{4}$ and $\mathrm{NO}_{2}^{-}$oxidizing populations declined sharply. These results further support the conclusion that autotrophic bacteria play a central role in the generation and maintenance of $\mathrm{NO}_{3}^{-}$and $\mathrm{NO}_{2}^{-}$gradients.

The spatial distribution of the individual groups of bacteria in the gels after 12 weeks incubation at $20^{\circ} \mathrm{C}$ followed a similar pattern to those recorded in Kingoodie Bay sediments (Tables 2 and 3). Nitrifying and potential nitrate respiring bacteria were dominant in the oxic $0-1 \mathrm{~cm}$ horizons of the gels and cell populations decreased with depth, although the decline in the nitrate respiring populations was less rapid than for the nitrifiers, which could not be detected at depths greater than $1 \mathrm{~cm}$. Maximum populations of sulphate reducing bacteria were recorded in the 2-3 cm horizon of the gels and the spatial distribution was similar to that observed in Kingoodie Bay sediments. These results demonstrate that the physico-chemical gradients and spatial 
Table 3. Distribution of nitrifying, $\mathrm{NO}_{3}^{-}$respiring and sulphate reducing bacteria in a stabilized gel after 12 weeks incubation at $20^{\circ} \mathrm{C}$

\begin{tabular}{|c|c|c|c|c|c|}
\hline $\begin{array}{l}\text { Sediment } \\
\text { depth } \\
\text { (cm) }\end{array}$ & $\begin{array}{c}\mathrm{NH}_{\mathbf{t}}^{+} \\
\text {oxidizing } \\
\text { bacteria }\end{array}$ & $\begin{array}{c}\mathrm{NO}_{2} \\
\text { oxidizing } \\
\text { bacteria }\end{array}$ & $\begin{array}{c}\text { Denitrifying } \\
\text { bacteria }\end{array}$ & $\begin{array}{c}\text { Bacteria } \\
\text { dissimilating } \\
\mathrm{NO}_{3}^{-} \text {to } \mathrm{NH}_{4}^{+}\end{array}$ & $\begin{array}{c}\text { Sulphate } \\
\text { reducing } \\
\text { bacteria }\end{array}$ \\
\hline $\begin{array}{c}0-0.5 \\
0.5-1 \\
1-2 \\
2-3 \\
3-4 \\
4-5\end{array}$ & $\begin{array}{c}8.2 \times 10^{4} \\
8.0 \times 10^{3} \\
\text { ND } \\
\text { ND } \\
\text { ND } \\
\text { ND }\end{array}$ & $\begin{array}{c}1.0 \times 10^{4} \\
6.2 \times 10^{3} \\
\text { ND } \\
\text { ND } \\
\text { ND } \\
\text { ND }\end{array}$ & $\begin{array}{l}3.0 \times 10^{5} \\
2.0 \times 10^{6} \\
2.0 \times 10^{6} \\
2.5 \times 10^{5} \\
1.8 \times 10^{5} \\
3.1 \times 10^{4}\end{array}$ & $\begin{array}{l}6.2 \times 10^{6} \\
3.5 \times 10^{6} \\
1.2 \times 10^{6} \\
2.2 \times 10^{6} \\
5.0 \times 10^{5} \\
2.0 \times 10^{5}\end{array}$ & $\begin{array}{l}1.4 \times 10^{2} \\
2.1 \times 10^{3} \\
4.3 \times 10^{4} \\
3.8 \times 10^{6} \\
1.2 \times 10^{6} \\
1.8 \times 10^{5}\end{array}$ \\
\hline
\end{tabular}

distribution of bacterial populations which developed within the gel systems were similar to those found in the surface sediments of Kingoodie Bay, and provide the basis of a model system for determining the parameters governing the distribution of bacteria in these environments.

\section{DIsCUSSION}

The significance of spatial and temporal heterogeneity of natural environments on the activities of microbial communities is widely recognized (Jørgensen, 1980; Wimpenny, 1981 ; Bull \& Slater, 1982; Jones, 1982; Wimpenny et al., 1983). However, the experimental methodology currently available to study these activities in situ is either insufficiently sensitive or discrete to probe these micro-environments without destroying their structural integrity, although considerable advances have been made recently in the development and application of micro-electrodes for measuring physico-chemical gradients in marine sediments (Revsbach et al., 1980). In order to study how microbial communities function in natural environments, it is often necessary to use model systems to identify the key processes involved. In operating simple model systems it is essential to establish how closely the model simulates the environmental conditions under investigation. The results presented in this paper show that the physico-chemical gradients (Figs 1 and 2) and spatial distribution of the microbial populations which develop in the gel systems were similar to those found in siru in Kingoodie Bay sediments. In this study we have investigated the effects of opposing gradients of $\mathrm{O}_{2}$ and $\mathrm{NH}_{4}$ on the development and spatial distribution of nitrifying, nitrate respiring, sulphate reducing and methanogenic bacteria in the absence of exogenous carbon sources, except for those introduced with the sediment inoculum. In estuarine and marine sediments $\mathrm{NH}_{4}$ concentrations generally increase with depth as a consequence of ammonification (Serensen, 1978; Owens et al., 1979; Stanley et al., 1981). $\mathrm{NH}_{4}^{+}$generated in smaller quantities as an end-product of $\mathrm{NO}_{3}^{-}$respiration supplements that derived by ammonification (Macfarlane \& Herbert, 1984). In the gel model system the only inorganic nitrogen source present was $10 \mathrm{mM}-\left(\mathrm{NH}_{4}\right)_{2} \mathrm{SO}_{4}$ and this was introduced in the source layer in order to simulate the $\mathrm{NH}_{\downarrow} \downarrow$ pool. The upward diffusion and $\mathrm{NH} \pm$ gradient which subsequently developed followed a profile similar to that recorded in the sediments albeit an order of magnitude greater. $\mathrm{NO}_{3}^{-}$and $\mathrm{NO}_{2}^{-}$production in the aerobic $\mathrm{0}-1 \mathrm{~cm}$ horizon of the gels resulted from the activities of autotrophic nitrifying bacteria which could only be detected in this zone. Maximum populations of potential $\mathrm{NO}_{3}^{-}$respiring bacteria in the gels were also present in the oxic $0-1 \mathrm{~cm}$ horizon, although it is debatable whether these bacteria were respiring $\mathrm{NO}_{3}$ in situ, since at the recorded dissolved $\mathrm{O}_{2}$ tensions synthesis of dissimilatory $\mathrm{NO}_{\overline{3}}^{-}$and $\mathrm{NO}_{2}$ reductase would be repressed (Dunn et al., 1979). These results indicate that autotrophic nitrifying bacteria play a central role in establishing and maintaining $\mathrm{NO}_{3}^{-}$and $\mathrm{NO}_{2}^{-}$gradients in the gel system. The addition of $\mathrm{N}$-serve, a specific inhibitor of $\mathrm{NH}_{4}$ oxidation (Shattuck \& Alexander, 1963), to inoculated gels at zero time totally suppressed the production of $\mathrm{NO}_{2}^{-}$and $\mathrm{NO}_{3}^{-}$gradients whilst the addition of this inhibitor to established gels resulted in the rapid disappearance of the $\mathrm{NO}_{3}^{-}$ and $\mathrm{NO}_{\overline{2}}^{-}$gradients. These results substantiate the findings of Vanderborght \& Billen (1975) that nitrification was responsible for $\mathrm{NO}_{3}^{-}$and $\mathrm{NO}_{2}^{-}$gradients which are found in an artificial lagoon at Ostend, and indicate a similar role for nitrifying bacteria in Kingoodie Bay sediments. 
The relationship between the aerobic nitrifying bacteria and the facultatively anaerobic $\mathrm{NO}_{3}^{-}$ respiring bacteria is probably complex and tightly coupled. The data presented in this paper show that not only are maximum populations of both groups of bacteria present in the same depth horizons but that this zone is also the site of maximum activity (Table 1). These results indicate that both processes are occurring simultaneously in the oxidized surface sediments in Kingoodie Bay and corroborate the field experiments of Sørensen (1978) and Koike \& Hattori (1978). Field data (Table 1) show that denitrification was the principal route of $\mathrm{NO}_{3}^{-}$respiration in Kingoodie Bay sediments and $\mathrm{NO}_{3}$ dissimilation to $\mathrm{NH}_{4}^{+}$was a minor, but nevertheless not inconsequential process. The latter process in terms of intermediates is the reverse of nitrification and it is interesting to speculate that an internal nitrogen cycle may operate between the nitrifying bacteria and the nitrate respiring bacteria. Experimental evidence to support this hypothesis has been obtained using a multi-stage diffusion chemostat in which a $\mathrm{NO}_{3}^{-}$ respiring Vibrio sp. supported the growth of Nitrosomonas sp. and Nitrobacter sp. (Macfarlane, 1983).

In addition to aerobes and facultative anaerobes, populations of strict anaerobes such as sulphate reducing bacteria and methanogens also developed in the deeper regions of the gels, where the redox potential was sufficiently low to initiate growth. Methanogenesis and sulphate reduction occurred in the same depth horizons in Kingoodie Bay sediments but the latter process was dominant. These data are in agreement with those obtained by Senior et al. (1982) for saltmarsh sediments. A similar distribution of sulphate reducing bacteria and methanogens developed within the gel model sediment system and $\mathrm{CH}_{4}$, identified by gas chromatography. was trapped in the agar source layer.

In summary, the gel model system described offers considerable promise as a research tool for the investigation of microbial interactions in estuarine sediments. The system is reproducible and, whilst it does suffer some disadvantages such as the lack of biopertubation and absence of either gas or solute exchange, it nonetheless permits the analysis of microbial processes which are presently unobtainable by other means.

This work was supported by a research grant (GR/3/4208) to R. A. H. from the Natural Environmental Research Council. M. A. R. acknowledges the receipt of a SERC studentship. We are grateful to Dr J. W. T. Wimpenny for useful discussions during the course of this work.

\section{REFERENCES}

ALEXANDER, M. (1965). Most probable number method for microbial populations. In Methods of Soil Analysis, Pp. 1467-1472. Edited by C. A. Black. Madison: American Society of Agronomy.

American Public Health Association (1974). Standard methods for the examination of water and wastewater. Washington DC: American Public Health Association.

Billen, G. (1976). A method for the evaluation of nitrifying activity in sediments by dark ${ }^{14} \mathrm{C}$-bicarbonate incorporation. Woter Research 10, 51-57.

BILLEN, G. (1982). Modelling the processes of organic matter degradation and nutrients recycling in sedimentary systems. In Sediment Microbiology. Special Publications of the Society for General Microbiology. pp. 15-52. Edited by D. B. Nedwell \& C. M. Brown. London: Academic Press.

Bull, A. T. \& Slater. H. J. (1982). Microbial Interactions and Communities. London: Academic Press.

Dunn, G. M., Herbert, R. A. \& Brown, C. M. (1979). Influence of oxygen tension on nitrate respiration by a Klebsiella sp. growing in chemostat culture. Journal of General Microbiology 112, 379-383.
JONES, J. G. (1982). Activities of aerobic and anaerobic bacteria in lake sediments and their effect on the water column. In Sediment Microbiology. Special Publications of the Society for General Microbiology, pp. 107-145. Edited by D. B. Nedwell \& C. M Brown. London: Academic Press.

JORGENSEN, B. B. (1977). Bacterial sulphate reduction within reduced microniches of oxidised marine sediments. Marine Biology 41, 7-17.

Jorgensen, B. B. (1980). Mineralisation and the bacterial cycling of carbon, nitrogen and sulphur in marine sediments. In Contemporary Microbial Ecology, pp. 239-25I. Edited by D. C. Ellwood, J. N. Hedger, M. J. Latham, J. M. Lynch \& J. H. Slater. London: Academic Press.

KeIth. S. M. \& Herbert, R. A. (1982). Effect of nitrogen source and availability on mixed populations of strict anaerobes grown in continuous culture. Society for General Microbiology Quarterly 9, M9.

KoIKe, I. \& Hattori, A. (1978). Simultaneous determinations of nitrification and nitrate reduction in coastal sediments by a ${ }^{15} \mathrm{~N}$-dilution technique. Applied and Entironmental Microbiolog. 35, 853 857. 
Macfarlane, G. T. (1983). Physiology of dissimilatory. nitrate reduction and nitrification in estuarine sediments. PhD thesis, University of Dundee. UK

Macfarlane, G. T. Herbert, R. A. (1984). Dissimilatory nitrate reduction and nitrification in estuarine sediments. Journal of General Microbiology 130. 2301 -2308.

Mechalas, B. J. (1974). Pathways and environmental requirements for biogenic gas production in the oceans. In Natural Gases in Marine Sediments. pp. 12 25. Edited by 1. R. Kaplan. New York: Plenum Press.

Owens. N. J. P. Christofi, N. \& Stewart, W D. P. (1979). Primary production and nitrogen cycling in estuarine environments. In Ciclic Phenomena in Marine Plants and Animals, pp $249-258$. Edited by E. Naylor \& R. G. Hartnoll. Oxford: Pergamon Press.

Postgate, J. R. (1979). The Sulphate Reducing Barreria Cambridge: Cambridge University Press.

Revibach, N. P., Jgrgensen. B. B. \& Blackburn. T. H. (1980). Oxygen in the sea-hottom measured with microelectrodes. Science 207, I355 1356

Senior, E., l.jndostrom, E. B. Banat, I. M. \& Nedwell, D. B. (1982). Sulfate reduction and methanogenesis in the sediment of a salt marsh on the east coast of the United $K$ ingdom. Applied and Entironmental Microbiology 43. 987.996.

Shattuck, G. E. \& Alexander, M. (1963). A differential inhibitor of nitrifying bacteria. Proceedings. Soil Science Society of America 27, 600-601

Sorensen, J (1978). Capacity for denitrification and reduction of $\mathrm{NO}_{3}^{-}$to $\mathrm{NH}_{+}^{+}$in a coastal marine sediment. Applied and Entironmental Microbiology 35. 301-305.

SorokIN, Y. I. (1962). Experimental investigation of bacterial sulfate reduction in the Black Sea using $\mathbf{S}^{35}$. Microbiology 31. 329-335 (English translation of Mikrobiologiya).

Stanley, S. O., Leftley, J. W. Lightroot, A., Robertson, N., Stanley, I. M. \& VanCe, I. (1981). The Loch Eil project : sediment chemistry, sedimentation and the chemistry of the overlying water in Loch Eil. Journal of Experimental Marine Biology and Ecology 55, 299-313

VANDERborGht. J. P. \& Billen. G. (1975). Vertical distribution of $\mathrm{NO}_{3}$ concentration in interstitial water of marine sediments with nitrification and denitrification. Limnology' and Oceanography 20. 953.961

WIMPENNY, J. W. T. (1981). Spatial order in microbial ecosystems. Biological Reviews 56, 295-342.

Wimpenny. J. W. T., COOMBS, J. P., Lovitt, R. W. \& WhitTAKer, S. (1981). A gel-stabilized model ecosystem for investigating microbial growth in spatially ordered solute gradients. Journal of General Microbiology 127, 277-287.

WIMPENNY, J. W. T. LovitT, R. W. \& Coomes, J. P. (1983). Laboratory model systems for the investigation of spatially and temporally organised microbial ecosystems. In Microbes in their Natural Entironments, pp. $66-117$. Edited by J. H. Slater, R. Whittenbury \& J. W. T. Wimpenny. Cambridge: Cambridge University Press.

WooD, E. J. F. (1965), Marine Microbial Ecology. London: Chapman \& Hall. 